\title{
A CIDADE DO PENSAMENTO ÚNICO: DESMANCHANDO CONSENSO
}

\author{
ARANTES, Otília, VAINER, Carlos, MARICATO, Erminia.
}

Joāo Sette Whitaker Ferreira

Doutorando do curso de pós-graduação e professor de planejamento da FAUUSP

Em 1995, Ignacio Ramonet cunhava pela primeira vez, no Le Monde Diplomatique, o termo pensamento único, como a "tradução em termos ideológicos com pretensões universais, dos interesses de um conjunto de forças econômicas, e em particular das do capital internacional" O jornalista alertava para a hegemonização - no sentido de que não deixava espaço para contrapontos - de um instrumental ideológico que visava impor universalmente o domínio absoluto da economia e do mercado sobre os rumos políticos, sociais e culturais do mundo globalizado pós-derrocada soviética. Um modelo que chegara aqui com força total desde 1990, pela aplicação por nossas elites da cartilha do Consenso de Washington. Nesse contexto, as cidades não só cumpriram o papel de portas de entrada para essa imposição como se tornaram elas mesmas instrumentos de competitividade e enriquecimento na nova economia global. Infelizmente para os que acreditam no papel transformador da crítica ao status quo, a maioria das análises sobre o urbano na era da globalização, disponíveis até hoje, endossaram esse papel e caíram no senso comum (ou na armadilha ideológica) da inevitabilidade e inexorabilidade do pensamento único. Por sorte, há exceções. A cidade do pensamento único é uma delas.

No primeiro texto do livro, Otília Arantes revela como surge já nos anos 70 , com a crise do fordismo-taylorismo, uma nova matriz liberal de planejamento, inspirada na gestão empresarial e baseada na idéia da cidade como máquina de crescimento, isto é, "máquina urbana de produzir renda" e que entre outras designações, tornou-se conhecida por planejamento estratégico. Segundo essa matriz, sobreviverão, no mundo global de extrema competitividade, as cidades que conseguirem uma coalizão entre as elites fundiárias e os empreendedores de negócios "decorrentes das possibilidades econômicas dos lugares" visando o crescimento econômico a qualquer preço por meio da obtenção de vantagens na competição permanente entre lugares pela atração do escasso e volátil capital internacional. No centro desse processo, que coagiu o "espetáculo como forma de resistência" para transformá-lo em "forma de controle social" a cultura aparece como um novo e fantástico empreendimento econômico, que facilita a fabricação de consensos em torno da idéia de que somente a inserção na rede global de cidades será capaz de gerar crescimento, empregos e modernidade. Associados aos políticos, ao grande capital e aos promotores culturais, os planejadores urbanos, agora planejadores-empreendedores, tornaram-se peças-chave dessa dinâmica. Esse modelo de mão única, que passa invariavelmente pela gentrificação de áreas urbanas "degradadas" para torná-las novamente atraentes ao grande capital por meio de megaequipamentos culturais, tem dupla origem, americana (Nova York) e européia (a Paris do Beaubourg), atingindo seu ápice de popularidade e marketing em Barcelona, e difundido-se pela Europa nas experiências de Bilbao, Lisboa e Berlim. 
Otília ressalta a impossibilidade de alguém "minimamente responsável" propor a aplicação desse modelo que reduz a cidade a mero espaço de negócios, no contexto social dos países subdesenvolvidos. Pois bem, Carlos Vainer nos lembra que nossas elites não primam exatamente pela responsabilidade. Em seu segundo texto, Vainer testemunha a implantação do Planejamento Estratégico da Cidade do Rio de Janeiro. Uma "bem orquestrada farsa" com o objetivo de legitimar "projetos caros aos grupos dominantes da cidade" a saber, tudo aquilo que permitiria a produção da "máquina de crescimento" carioca, competitiva e vendável à dinâmica do capital internacional. Vainer desnuda as manobras para colocar em escanteio as reivindicações populares, dando espaço aos interesses dos empreendedores e a um agressivo marketing para criar falsos consensos que legitimassem a farsa. Tais açōes soam coerentes com as colocações de seu primeiro texto, no qual mostra, pela análise exaustiva das argumentaçōes teóricas dos consultores barcelonenses, a mise-en-place de um arsenal político-ideológico-empresarial destinado a impor universalmente, à maneira do pensamento único e com a indefectivel cooperação das elites do Terceiro Mundo, a matriz do planejamento estratégico, segundo a qual a sobrevida das cidades está em sua transformação em mercadoria.

Com o mesmo brilho dos textos anteriores, Ermínia Maricato fecha o livro perguntando se essa nova matriz seria resultante "de um processo endógeno calcado na práxis urbana" ou seguiria novamente um "caminho de dominação econômica, política e ideológica de inspiração externa, reproduzindo modelos alienados de nossa realidade" Ermínia Maricato passeia com desenvoltura pela história do planejamento urbano no Brasil, demonstrando a infinita sobreposição de modelos de dominação que, utilizando-se do controle sobre o poder político e a burocracia estatal, a legislação e a economia permitiram a eterna produção de um espaço urbano de segregação espacial e exclusão social, voltado apenas aos interesses das elites dominantes. Ermínia mostra que a praxis urbana no Brasil tem origens na nossa estrutura colonial, e é hoje produtora da cidade desigual, dividida entre um pequeno território legal onde se reproduzem os interesses econômicos das elites e a enorme parcela da cidade ilegal, abandonada à sua própria sorte por um Estado e um planejamento urbano que há muito se descolaram, pois era esse seu interesse - da realidade da maioria. Como seria possivel, nessa matriz social, oriunda de uma "industrialização de baixos salários" que necessita de uma profunda reestruturação política, econômica e social, a importação de um modelo de cidade global que exacerba a exclusão e a criação de oportunidades para poucos privilegiados? Como diz a autora, essa representação da "cidade" é uma "ardilosa construção ideológica que torna a condição de cidadania um privilégio e não um direito universal: parte da cidade toma o lugar do todo" $\mathrm{E}$, mostrando que também na área urbana podem, sim, existir - e de fato existem - propostas efetivas que se contraponham ao pensamento único, Ermínia Maricato finaliza analisando diversos instrumentos de planejamento voltados para o necessário desenvolvimento includente das nossas cidades.

Como é de praxe na coleção Zero à Esquerda, este livro é radical. Radical no sentido colocado por Bobbio, ou seja, que tem como "claro objetivo o abandono de qualquer hipótese temporizadora" na busca de uma "vigorosa renovação nos vários setores da vida civil e da organização política" Por isso mesmo, esse é um livro imprescindivel.

Em tempo: para esta resenha não ficar sem críticas, perguntamos por que a ótima apresentação do livro ficou sem assinatura. 